\title{
RELATION OF NATURE AND HUMANS AS REPRESENTED IN ERNEST- HEMINGWAY'S “THE OLD MAN AND THE SEA”
}

\section{NONGMAITHEM SURAJ KUMAR}

Research Scholar, Nagaland University, Nagaland, India

\begin{abstract}
Ernest Hemingway is one of the most famous novelists all around the globe. He has written many books and "The Old Man and the Sea" stands out at the top. The book had fetched him both the "Pulitzer Prize" and "Nobel Prize" in 1953 and 1954 respectively. The book has got lots of natural elements present in it. The way the author presents nature is quite marvellous, catchy and signifies a lot of importance. The importance of nature in the life of human beings is beautifully shown and presented in the novel. The word used by the author is simple, direct and easy to understand.

Research Aims: To show how an author represents nature in writings.

Key Findings: It is found that Hemingway is a natural writer and represents nature beautifully.

KEYWORDS: Gulf-Stream, Africa, Traps, Flying-Fishes \& Sea-Water
\end{abstract}

Received: Jul 25, 2017; Accepted: Aug 10, 2017; Published: Aug 16, 2017; Paper Id.: IJELAUG201724

\section{INTRODUCTION}

Ernest Hemingway is one of the most powerful short story writers and novelist of America. Most of his stories and novels are based upon his personal experiences. He occupies a prominent place in the American Literary history for his never ending role in the areas of fictional writings. Hemingway has written in a simple but unconventional style, with the problems of war, hatred, violence, relationship of man towards nature and death as the themes. His novels present a symbolic interpretation of human life.

Ernest Hemingway was born on July 21, 1899 in Oak Park, Illinois to Dr. Clarence Hemingway and Grace Hall Hemingway. He was an excellent student of English classes despite this he was an average student. Hemingway got a job of a reporter for Kansas City Star just after graduation in 1917. His work covers the collection of police stories; hospital news etc. and then became an ambulance driver for Red Cross Society. In 1921, he married Hadley Richardson in Horton Bay, Michigan. She was the first of the four wives. They had been doing some sort of writing for living.

In 1927, Hemingway married Pauline Pfeiffer in the Paris church of Passy after getting divorced from the former wife. This marriage was too short lived. Both got divorced after Hemingway returned from The Spanish Civil war. He then married his third wife Martha Gellhorn and soon broke up. During his stay in London during the war, Hemingway began an affair with the woman who would become his fourth wife - journalist Mary Welsh. Due to deteriorating health, Hemingway was admitted to Mayo hospital in 1960 where he was asked to stay there for two months. He received electroshock therapy for his depression and was sent home after two-month stay in the hospital.

But in April 1961, he was re admitted again, stayed there for two months and was discharged on June 26, 
1961. Only after a few days of being discharged from the hospital, Hemingway ended his life tragically, with a shotgun blast to his head on early Sunday morning of July 2, 1961 before anyone got up. He died instantly. One of the most precious books that Hemingway wrote was "The Old Man and the Sea" which won him both the Pulitzer (1953) and Nobel Prize (1954).

\section{ABOUT THE BOOK}

This book deals about the friendship between an old man and a young boy. It also depicts about the aesthetic bond of relationship with nature and human. It also shows how man depends on nature for his food, travel and living. The book also shows how man has to overcome the barriers of nature to survive safely. The book also tells us to have a good relationship with nature as it is through nature that we are living peacefully and comfortably.

\section{RELATION OF NATURE AND HUMAN}

The significance of natural element like water is found in the novel. "He was an old man who fished alone in a skiff in the Gulf Stream and he had gone eighty-four days now without taking a fish." (3) The above is the opening line of the novel, here old man is seen travelling alone in the in the Gulf Stream for fishing. But to his dismay he has not caught any. Gulf Stream is an ocean current favourable for the growth of fishes. Despite this the luck of the old man did not favour him. Water finds an importance not only as a source of drinking but also for survival of an individual. This shows the dependence on nature by humans for their survival.

"He was asleep in a short time and he dreamed of Africa when he was a boy and the long, golden beaches and the white beaches, so white they hurt your eyes, and the high capes and the great brown mountain." (15) Here, too one can see the intimate relationship of nature and man that even in the old age the old man still sees the wonder of nature in his dreams. His bond with nature is truly remarkable as he can name all the natural places he had been living with when he was a small kid. The beauty of natural Africa is beautifully shown in the given lines like the forest covered mountain and beautiful beaches which is found plentifully in Africa. This shows the relation of human and nature.

"He was very fond of flying fishes as they were his principal friends in the ocean." (19) To have a companion has always been the nature of all the living beings on the earth it may be either natural or inanimate beings. Here the old man too keeps fishes as the companion because to stay alone is impossible in the vast ocean. He was usually accompanied by these fishes whenever he travels put in the ocean for fishing. Flying fishes are the kind of fishes which are found in big seas and can travel swiftly. This shows the importance of companion between man and other beings.

"His choice was to stay in the deep dark water far out beyond all snares and traps and treacheries." (36) Ocean water symbolises home for water animals specially fishes. Here too, Marlin the big fishes wish to stay in the depth of the ocean so that no harm is done. The survival of the fish depends on the vast ocean. People especially the fisherman usually keep traps like nets and various other methods to catch fishes and this makes the fishes wishes to stay in the deep water to avoid the dangers that lies above the surface of the ocean. This shows that even fishes are afraid to come up to the surface of the water as they might fell in the traps laid the higher beings specially humans. The above line shows the cruelty of human over other natural beings existing together with them.

"He settled comfortably against the wood and took his suffering as it came and the fish steadily and the boat moved slowly through the dark water" (48) the above lines represents the competition between the forces of nature viz. and 
human being represented by old man. While trying to make the boat go in a desired direction along the fish, the old man hurt a little but soon got control over it. This shows the dominant figure of human over natural elements and nature in which humans are trying to control it are beautifully crafted by the author.

"He could not see the fish's jumps but only heard the breaking of the ocean and the heavy splash as he fell." (63)The control of man over the other natural creature is seen here. The old man had complete control over the fish and as he fell down for rest all he could hear was the beautiful sound of ocean water splashing against his boat. This also shows the satisfaction of the old man against the fish. This further shows the relation of nature and man in terms of superiority one over another.

"He lifted some sea water with his left hand and put it on his head." (67-68)The availability of natural resource is shown in the above line. The old man got tired of handling the fish and to replenish this, he got hold of some water from the sea and put on his head to cool off. This shows the dependence of man on nature even for simple things.

The account of the natural vast sea coming to life at the dawn was one of the most moving passages in the story, supplemented later with the drama of the great pursuit. This comes when the old man saw the huge size of the Marlin for the first time. Here, the author too plays very close attention to the movements of the currents of the wind, the rippling of the water, the movements of the turtles, birds, fishes, the rising of the stars, moon and the sun. The author has employed simply not the sense of nature's vastness but also her enhancement. This magic enhancement has added an aesthetic dimension to the adventure of Santiago whose heroism invests it with moral meaning and whose invocation of comradeship and the supply of identity with emotional grandeur.

\section{CONCLUSIONS}

The author through "The Old Man and Sea" makes a realisation to the readers that man is a part of the whole universe. Further, man, fish and all other creatures in nature are similar from the cosmic point of view. Though man may not treat other creatures as same, but to the universal conscience that treats man and other creations of nature as equals. The story is a presentation of life as a struggle against the indestructible and unconquerable forces in which a kind of victory is possible. With the novel, Hemingway had written an epic metaphor for life. The fish is the creation of the natural world with its ambiguous and unbreakable essence. It can't be taken home as a trophy of some tournament. In the struggle between life and death, the problem of right and wrong seems meagre.

Hemingway is a great writer. The way he portrays his natural phenomenon in his books are simply marvellous. $\mathrm{He}$ has a great skill of writing, his choice of selection of landscapes in different books is good and above all of this his writing mainly deals with his personal experiences. He was indeed a complete wizard of natural setting in most of his works. Due to this he can also be called as a natural writer.

\section{REFERENCES}

1. Baker, Carlos. (1969).Ernest Hemingway: A Life Story. New York: Charles Scribner's Sons.

2. Hemingway, Ernest. (2004. The Old Man and the Sea. London: Arrow Books.

3. Neill, Kate O. (2009). The Environment and International Relations. U.K: Cambridge University Press.

4. Nelson, Raymond S. (1984).Ernest Hemingway: Life, Works and Criticism. Canada: York Press Ltd.

5. Scafella, Frank. (1973).Hemingway: The Writer as Artist. New Jersey: Princeton University Press. 
6. Taylor, Paul. (1986). Respect for Nature: A Theory of Environmental Ethics. Princeton: Princeton University Press. 